\title{
REgulating LAWYER COMPETENCE AND QUALITY OF SERVICE
}

\section{GAVIN MACKENZIE*}

Law societies serve two central roles: the regulation of ethical standards in legal practice and the enforcement of competent legal practice. Despite having these two functions, the focus of Canadian law societies has tended to centre on ethics, while the enforcement of competence has often been overlooked. The author examines various Canadian law societies' rules of professional conduct. He then considers possible solutions to the problem of lawyer incompetence, including the implementation by law societies of programs directed towards prevention, such as continuing legal education and practice review programs, in order to ensure competent legal practice.
Les barreaux servent essentiellement deux fonctions centrales : la réglementation des normes de déontologie de la pratique juridique et l'exécution de la pratique juridique compétente. Malgré ces deux fonctions, les barreaux canadiens ont tendance à cibler la déontologie alors que l'exécution de la compétence est souvent négligée. L'auteur examine les diverses règles de conduite professionnelle des barreaux canadiens. Ensuite, il examine des solutions éventuelles au problème de l'incompétence des avocats, y compris la mise en cuvre, par les barreaux, de programmes axés sur la prévention tels que l'éducation permanente juridique et les programmes de revue des pratiques dans le but d'assurer une pratique juridique compétente.

\section{TABLE OF CONTENTS}

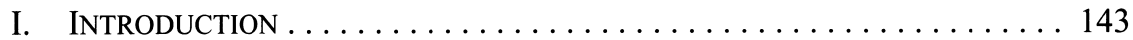

II. RULES OF PROFESSIONAL CONDUCT $\ldots \ldots \ldots \ldots \ldots \ldots \ldots \ldots \ldots \ldots \ldots \ldots$

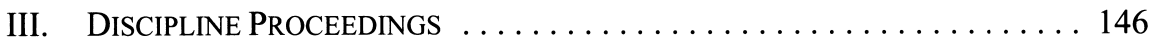

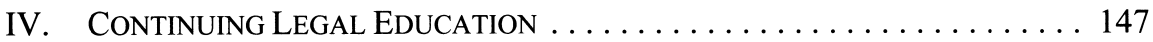

V. InSURANCE LosS PREVENTION PRograms $\ldots \ldots \ldots \ldots \ldots \ldots \ldots \ldots \ldots$

VI. Practice Review Programs . . . . . . . . . . . . . . . . . . 147

VII. Solicitors' Negligence Litigation $\ldots \ldots \ldots \ldots \ldots \ldots \ldots \ldots . . \ldots \ldots$

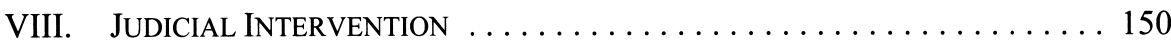

IX. CONCLUSION ............................... 150

\section{INTRODUCTION}

Our keynote speaker, Harry W. Arthurs, delivered a paper in 1994 on the subject of competence. ${ }^{1}$ He wrote as follows: "[l]aw societies have exhibited an invincible repugnance to the idea that they should use their knowledge and power to discipline incompetent lawyers, the very group that professional self-government is designed to suppress."

His point is well-taken. As regulators, law societies have two core business lines: ethics and competence. Law societies exist to maintain high standards of ethics and competence to protect the public. In the past - and to a considerable extent we are vulnerable to the same criticism today - we have sometimes been guilty of subordinating the maintenance of high standards of competence to the enforcement of ethical standards through our discipline process as a priority.

* $\quad$ Partner, Heenan Blaikie LLP, Toronto; Treasurer, Law Society of Upper Canada.

$1 \quad$ H.W. Arthurs, “The Dead Parrot: Does Professional Self-regulation Exhibit Vital Signs?”(1995) 33 Alta. L. Rev. 800. 
My sense is that since Arthurs wrote his paper in 1994, there has been a heightened awareness of the need for reform, a changing attitude toward continuing competence by law societies, and that some - albeit inadequate - progress has been made. This article examines what we are doing at law societies, and the alternative courses available to enable us to do a better job in the future.

\section{Rules of Professional Conduct}

Canadian rules of professional conduct impose on lawyers a "duty to be competent to perform any legal services undertaken on the client's behalf," 3 and a duty to serve clients in a "conscientious, diligent and efficient manner so as to provide a quality of service at least equal to that which lawyers generally would expect of a competent lawyer in a like situation."

Competence in the context of these duties means more than "formal qualification to practise law,"5 and "involves more than an understanding of legal principles." Clients are entitled to expect that a lawyer who undertakes a particular matter on their behalf is either competent to handle the matter or is "able to become competent without undue delay, risk or expense to the client."7 The rules of professional conduct make it clear that " $\mathrm{t}] \mathrm{he}$ lawyer who proceeds on any other basis is not being honest with the client, [and] [t]his is an ethical consideration and is to be distinguished from the standard of care that a court would apply for purposes of determining negligence." 8

The rules specify that "lawyer[s] must be alert to recognize any lack of competence for a particular task and the disservice that would be done the client by undertaking that task."9 In such circumstances, lawyers should either decline to act or obtain the client's instructions to retain, consult, or collaborate with a lawyer who is competent in that field. ${ }^{10}$ The rules also require lawyers to maintain competence by keeping abreast of developments in the branches of law in which they practice. ${ }^{11}$

The Law Society of Upper Canada's (LSUC) Rules of Professional Conduct, as a result of amendments that came into force in 2000 , now contain a detailed definition of the term

Canadian Bar Association (CBA), Code of Professional Conduct (Ottawa: Canadian Bar Association, 2006), c. II, r. 1 [CBA Code]. See also Law Society of Upper Canada (LSUC), Rules of Professional Conduct (21 February 2008), online: LSUC <http://www.lsuc.on.ca/regulation/a/profconduct/>, r. 2.01(2) [LSUC Rules]; Law Society of British Columbia (LSBC), Professional Conduct Handbook (December 2007), online: LSBC <http://www.lawsociety.bc.ca/publications_forms/handbook/ handbook_toc.html>, c. 3, rr. 1-2 [LSBC Handbook]. CBA Code, ibid., c. II, r. 2. See also LSUC Rules, ibid., rr. 2.01(1)-(2); LSBC Handbook, ibid., c. 3, r. 3.

CBA Code, ibid., c. II, cmt. 1.

Ibid. at c. II, cmt. 4.

Ibid. at c. II, cmt. 3 .

CBA Code, ibid., c. II, cmt. 3; LSUC Rules, supra note 3, r. 2.01(1) and accompanying commentary. CBA Code, ibid., c. II, cmt. 6.

CBA Code, ibid., c. II, cmt. 6; LSUC Rules, supra note 3, r. 2.01(1) and accompanying commentary; Barreau du Quebec, Code of Ethics of Advocates (23 February 2008), online: Barreau du Quebec $<\mathrm{http}: / /$ www. barreau.gc.ca/barreau/lois-reglements/index.html>, s. 3.01.01 [Quebec Code]. 
"competent lawyer" and require lawyers to perform any legal services undertaken on a client's behalf to the standard of a competent lawyer. ${ }^{12}$ The definition reads as follows:

2.01 (1) In this rule

"competent lawyer" means a lawyer who has and applies relevant skills, attributes, and values in a manner appropriate to each matter undertaken on behalf of a client including

(a) knowing general legal principles and procedures and the substantive law and procedure for the areas of law in which the lawyer practises,

(b) investigating facts, identifying issues, ascertaining client objectives, considering possible options, and developing and advising the client on appropriate courses of action,

(c) implementing, as each matter requires, the chosen course of action through the application of appropriate skills, including,

(i) legal research,

(ii) analysis,

(iii) application of the law to the relevant facts,

(iv) writing and drafting,

(v) negotiation,

(vi) alternative dispute resolution,

(vii) advocacy, and

(viii) problem-solving ability,

(d) communicating at all stages of a matter in a timely and effective manner that is appropriate to the age and abilities of the client,

(e) performing all functions conscientiously, diligently, and in a timely and cost-effective manner,

(f) applying intellectual capacity, judgment, and deliberation to all functions,

(g) complying in letter and in spirit with the Rules of Professional Conduct,

(h) recognizing limitations in one's ability to handle a matter or some aspect of it, and taking steps accordingly to ensure the client is appropriately served,

(i) managing one's practice effectively,

(j) pursuing appropriate professional development to maintain and enhance legal knowledge and skills, and

(k) adapting to changing professional requirements, standards, techniques, and practices. ${ }^{13}$ 
Finally, the LSUC Rules admonish lawyers that though a "mistake, even though it might be actionable for damages in negligence, would not necessarily constitute a failure to maintain the standard set by the Rule ... evidence of gross neglect in a particular matter or a pattern of neglect or mistakes in different matters may be evidence of such a failure regardless of tort liability." 14 Incompetence can give rise to disciplinary action. ${ }^{15}$

\section{Discipline Proceedings}

In practice, the enforcement of competency standards through disciplinary action has been limited generally to blatant cases of wilful and reckless failure to maintain even the most minimal standards of competence and quality of service. Despite the wording of the rules referred to above, incompetency, and in Ontario, unsatisfactory professional practice have usually been considered to be less culpable than professional misconduct, which traditionally has been defined as "conduct which would reasonably be regarded as disgraceful or dishonorable by solicitors of good repute and competency." ${ }^{, 16}$ Cases in which a lawyer's right to practise has been revoked by reason of incompetency are exceedingly rare. ${ }^{17}$ Lesser penalties, such as suspensions and reprimands, are seldom effective in rectifying competence problems. If the legal profession's only measure of an acceptable quality of service were the standard set by the results of discipline proceedings, it would never have to fear being criticized for establishing an unrealistic professional ideal. In discipline proceedings, the profession has regulated competence by reference to the lowest common denominator.

Fortunately, discipline proceedings are not the only possible method of regulating competence. Others include bar admission courses, continuing legal education, insurance loss prevention programs, practice review programs, solicitors' negligence litigation, and judicial intervention.

CBA Code, supra note 3, c. II, cmt. 9.

CBA Code, ibid., c. 11, cmt. 9; LSUC Rules, supra note 3, r. 2.01(2) and accompanying commentary. Myers v. Elman (1939), [1940] A.C. 282 at 288-89 (H.L.), referring to Darling J.'s definition of professional misconduct in Re Solicitor (1911), [1912] I K.B. 302.

In Re MacDonald (see Stephen E. Traviss, Synopses of Discipline Cases Considered by Convocation 1972-1984 [unpublished, archived at the LSUC], a report of discipline hearing panel adopted by Convocation, 20 February 1981 (Ontario), a lawyer was publicly reprimanded for maintaining a standard of practice lower than that required of a competent lawyer, and subsequently disbarred for misappropriation on 18 September 1981. See also Edmund B. Spaeth, Jr., "To What Extent Can a Disciplinary Code Assure the Competence of Lawyers?" (1988) 61 Temp. L. Rev. 1211; Susan R. Martyn, "Lawyer Competence and Lawyer Discipline: Beyond the Bar?" (1981) 69 Geo. L.J. 705; American Bar Association, Lawyer Regulation for a New Century: Report of the Commission on Evaluation of Disciplinary Enforcement (Chicago: American Bar Association, 1992) at 9-10. 


\section{Continuing Legal Education}

Canadian rules of professional conduct provide that lawyers should keep abreast of developments in fields in which they practice by engaging in continuing study and education. ${ }^{18}$ In a number of American jurisdictions continuing legal education is mandatory. ${ }^{19}$

In Ontario, while it does not require lawyers to undertake continuing legal education, the Law Society specifies minimum continuing legal education expectations and requires annual reporting by members of time devoted to continuing legal education.

Mandatory continuing legal education programs are no panacea, however. They have been criticized for requiring too few hours of continuing education, for failing to require that the programs taken are relevant to the practitioner's field of practice and, perhaps most importantly, for failing to address the most prevalent causes of problems. ${ }^{20}$ The most common competency problems are caused not by lawyers' failure to keep current in the law - the most frequent subject of continuing education programs - but rather by inadequate office systems and sloppy work habits, resulting in such problems as missed limitation periods, botched title searches, and failures to communicate appropriately with clients.

\section{Insurance Loss Prevention Programs}

Compulsory errors and omissions insurance, in those jurisdictions in which it exists, has enabled law societies to identify common problem areas and risks, and to implement loss prevention programs that have had some success. ${ }^{21}$

\section{Practice Review Programs}

In 1986, the LSUC created a standing committee of benchers with responsibility for professional standards. The impetus to form a professional standards committee originated due to a growing consensus that concerns about professional competence were being inadequately dealt with by means of the discipline process, and that remedial means would be more effective.

The professional standards department makes extensive use of experienced lawyers in private practice who conduct peer reviews of lawyers who are referred to the department, generally as a result of a history of complaints, professional liability claims, or audits that call their competence into question. The reviewers make recommendations designed to

CBA Code, supra note 3, c. II, cmt. 4, requires that lawyers maintain competence and provides that "lawyer[s] should keep abreast of developments in areas in which the lawyer practises." See also LSUC Rules, supra note 3, r. 2.01(1): the definition of the term "competent lawyer" requires lawyers to pursue appropriate professional development to maintain and enhance legal knowledge and skills. eds., The Quality Pursuit: Assuring Standards in the Practice of Law (Chicago: American Bar Association, 1989) 223 at 224. 
improve the lawyer's office management procedures and the quality of legal services provided.

In 2006, Convocation expanded its practice review program significantly by adding a preventive component to its existing remedial program. ${ }^{22}$ Lawyers in private practice who have been practising for between one and eight years may be selected for participation in the program, without regard to their history of complaints or liability claims. The goal of the program is to conduct approximately 420 preventive practice management reviews a year, together with approximately 80 remedial (or "focused") reviews. ${ }^{23}$

Convocation's decision to expand its practice review program in this way was influenced by a number of factors, including (1) changing public attitudes toward self-regulation and the need for improved quality assurance, (2) the successful adoption of similar programs in other self-governing professions (for example, the College of Physicians and Surgeons of Ontario has a "peer assessment" program, while the Institute of Chartered Accountants of Ontario has a "practice inspection" program), ${ }^{24}$ and (3) the success of the Law Society's own financial spot audit program. Benchers' concerns that a preventive practice review program may be regarded by members as unduly intrusive were allayed by the high satisfaction rate among lawyers whose practices had been selected for financial spot audits. Each member who had been audited in 2005 was surveyed. Ninety-three percent found the spot audit process constructive; 98 percent found the audit report useful; and almost 100 percent found the auditor's conduct to be professional and helpful. ${ }^{25}$

Although the cost of the practice review program is significant, the Law Society expects that the effect of inculcating strong practice management habits in lawyers during their early years of practice will result in a reduction in complaints and liability claims (with the attendant costs, direct and indirect, of resolving those complaints and claims) throughout their careers. This approach is designed to prevent deficiencies from becoming more serious regulatory issues, and to help marginal practitioners flourish.

\section{SOLICITORS’ NEgLigENCE Litigation}

The standard of care and skill enforced by the courts in solicitors' negligence litigation is that of a reasonably competent and diligent lawyer practising in the area in which the defendant practiced at the time of the alleged negligence. ${ }^{26}$ In order to succeed in establishing liability, it is not enough for a plaintiff to prove that the lawyer has made an error or given

LSUC, Professional Development, Competence and Admissions Committee, Report to Convocation (22 June 2006), online: LSUC <http://www.lsuc.on.ca/media/convjune06_pdca.pdf $>$ [LSUC Report].

Ibid. at introduction.

24 See College of Physicians and Surgeons of Ontario (CPSO), "Peer Assessment," online: CPSO $<$ http://www.cpso.on.ca/Info_physicians/peer2.htm>; Institute of Chartered Accountants of Ontario (ICAO), Practice Inspection Program, online: ICAO <http://www.icao.on/ca/CAfirms/Practice Inspection/FormsCompletionGuide/PIbooklet2007.pdf>.

$25 \quad$ LSUC Report, supra note 22 at 3.

26 See e.g. Tiffin Holdings Ltd. v. Millican (1964), 49 D.L.R. (2d) 216 at 218 (Alta. S.C.), rev'd (1965), 52 D.L.R. (2d) 674 (S.C. (A.D.)), rev'd [1967] S.C.R. 183, as quoted by Haddad J.A. in Spence v. Bell (1982), 39 A.R. 239 at 251 (C.A.), leave to appeal to S.C.C. refused, 17357 (15 November 1983). See also Hauck v. Dixon (1975), 10 O.R. (2d) 605 (H.C.); Stronghold Investments Ltd. v. Renkema (1984), 7 D.L.R. (4th) 427 at 434 (B.C.S.C.) [Stronghold]. 
advice on a view of the law that a court later holds to be untenable; the plaintiff must show that the error was such that an ordinarily competent lawyer practising in the area would not have made it. ${ }^{27} \mathrm{~A}$ lawyer will not be found liable by reason of a violation of competency standards in a case in which there is a rift of respectable professional opinion concerning the acceptability of the measures taken by the lawyer. ${ }^{28}$ However, in 1991, the Supreme Court of Canada held that the courts are not bound by expert evidence that the defendant's conduct conforms to the norms of practice of prudent lawyers in the same circumstances. ${ }^{29}$ The fact that a lawyer follows the common professional practice at the relevant time is not sufficient to avoid liability unless the common practice is demonstrably reasonable.

Lawyers may be found liable in tort as well as in contract, and may be found liable not only to clients but also to others who have foreseeably suffered harm as a result of their negligence. ${ }^{30}$ The Supreme Court of Canada's decision in a 1986 case, ${ }^{31}$ that lawyers may be concurrently liable in contract and tort, had the effect of extending limitation periods in some cases and of broadening the categories of remedies that are available to disgruntled clients.

Frequently, civil claims asserted against lawyers are framed as breaches of fiduciary duty. The courts have repeatedly affirmed, however, that not all duties of lawyers may be categorized as fiduciary duties. As Southin J. (as he then was), wrote in a 1987 decision:

The word "fiduciary" is flung around now as if it applied to all breaches of duty by solicitors, directors of companies and so forth. But "fiduciary" comes from the Latin "fiducia" meaning "trust". Thus, the adjective, "fiduciary" means of or pertaining to a trustee or trusteeship. That a lawyer can commit a breach of the special duty of a trustee, e.g., by stealing his client's money, by entering into a contract with the client without full disclosure, by sending a client a bill claiming disbursements never made and so forth is clear. But to say that simple carelessness in giving advice is such a breach is a perversion of words. The obligation of a solicitor of care and skill is the same obligation of any person who undertakes for reward to carry out a task. One would not assert of an engineer or physician who had given bad advice and from whom common law damages were sought that he was guilty of a breach of fiduciary duty. Why should it be said of a solicitor? $?^{32}$

Lawyers of course have a duty to follow clients' lawful instructions and will be responsible for any loss that may ensue as a result of their disobeying these instructions. Lawyers have a duty to seek instructions as necessary; they must not substitute their own judgment for actual client instructions, or what they expect the client's instructions would be if the client were asked. ${ }^{33}$

See e.g. Ormindale Holdings Ltd. v. Ray, Wolfe, Connell, Lightbody \& Reynolds (1980), 116 D.L.R. (3d) 346 (B.C.S.C.), aff'd (1982), 135 D.L.R. (3d) 577 (B.C.C.A.); Stronghold, ibid. Papadopoulos v. Anklewicz (1987), 60 O.R. (2d) 198 (H.C.).

Dorion v. Roberge, [1991] 1 S.C.R. 374; the Ontario Court of Appeal reached the same conclusion in Glivar v. Noble (1985), 8 O.A.C. 60 at 66: "if the risk of harm from following a prevailing practice is both foreseeable and readily avoidable, a solicitor is negligent in following that practice." See Hedley Byrne \& Co. Ltd. v. Heller \& Partners Ltd., [1964] A.C. 465 (H.L.); Anns v. Merton London Borough Council, [1978] A.C. 728 (H.L.); Tracy v. Atkins (1979), 105 D.L.R. (3d) 632 (B.C.C.A.). Central Trust Co. v. Rafuse, [1986] 2 S.C.R. 147, var'd [1988] 1 S.C.R. 1206. Girardet v. Crease \& Co. (1987), 11 B.C.L.R. (2d) 361 at 362 (S.C.); see also Fasken Campbell Godfrey v. Seven-Up Canada Inc. (1997), 142 D.L.R. (4th) 456 at 483 (Ont. Gen. Div.); Martin v. Goldfarb (1997), 31 B.L.R. (2d) 265 at 279-80 (Ont. Gen. Div.), rev'd (1998), 41 O.R. (3d) 161 (C.A.). See Osler v. Ford, [1936] O.W.N. 159 (H.C.). 


\section{JUDICIAL INTERVENTION}

In a profession that has become increasingly specialized, it is particularly important that lawyers abide by the admonition of the rules of professional conduct that when consulted about matters in fields in which they lack expertise and experience, they have a duty either to decline to act, or to retain, consult, or collaborate with lawyers who are competent in those fields. ${ }^{34}$ In a 1994 decision, the Ontario Court of Appeal allowed an appeal from a conviction on the ground that the incompetence of defence counsel at trial prevented the accused from having a fair trial. ${ }^{35}$ Defence counsel had failed to take the rudimentary step of interviewing witnesses who, he was told, would support his client's alibi. He had also failed to object to some dubious evidence of other acts of violence, and had not ordered a transcript of the preliminary hearing.

In at least one American case, a judge has intervened to prevent a lawyer from acting in a field in which the lawyer lacked the necessary experience. In a 1986 Florida case,$^{36}$ a Bankruptcy Court Judge dismissed an application because of the failure of the debtor's lawyer to file a required statement and plan. The debtor's lawyer acknowledged unfamiliarity with the filing requirements, and informed the Court that he had relied on the advice of an assistant clerk in the bankruptcy office who had informed him that all necessary forms had been filed. The Court ordered that the lawyer be discharged as the debtor's lawyer and be enjoined from further practice in the bankruptcy court until he completed a minimum of nine hours of continuing legal education in the field of bankruptcy law. "It is outrageous," the presiding Judge said by way of explanation for this order, "that an attorney, who has achieved a law degree and obtained admission to the Florida bar publicly admits that he practices based on advice of assistant court clerks and products available in a stationery store." 37

\section{Conclusion}

Perhaps because of increased public scrutiny and heightened public expectations, it has become evident in recent years that incompetent legal service can be as damaging to clients and third parties as unprofessional conduct of other kinds. The legal profession has done an appreciably better job of protecting the public from lawyers who have acted dishonestly than it has of protecting the public from lawyers who have acted incompetently. Lawyers in both categories bring discredit upon the profession. Both the public interest and the self-interest of the profession demand that law societies redouble their efforts to improve the competence of their members and protect the public against lawyers who are unwilling or unable to provide legal services of an acceptable quality. ${ }^{38}$

CBA Code, supra note 3, c. II, cmt. 6; LSUC Rules, supra note 3, r. 2.01(1) and accompanying commentary.

R. v. McKellar (1994), 19 O.R. (3d) 796 (C.A.).

Re Pearson, 70 B.R. 202 (Bankr. S.D. Fla. 1986).

Ibid. at 204.

See W.H. Hurlburt, “Incompetent Service and Professional Responsibility”(1980) 18 Alta. L. Rev. 145 at 149; Geoffrey C. Hazard, "Internal Management Controls Tend to Assure the Quality of Legal Services" The National Law' Journal 15:29 (22 March 1993) 15 at 15-16. 